\title{
WHAT CAN WE LEARN FROM A NARRATIVE REINTERPRETATION OF A MISSION (HI)STORY? REFLECTING ON THE MISSION HISTORY OF THE DUTCH REFORMED CHURCH ACCORDING TO WILLEM SAAYMAN
}

\section{Alfred Richard Brunsdon}

Department of Theology, North-West University, Mafikeng Campus, South Africa Alfred.Brunsdon@nwu.ac.za

\section{ABSTRACT}

On 16 May 2015, the well-known missiologist, Willem Saayman, passed away. In this article, his overview of the Dutch Reformed Church (DRC) mission history, Being Missionary, Being Human (2007), is revisited from the perspective of the narrative theory of White and Epston. This reinterpretation rests on the notion that history and religious traditions are structured as narratives that are open for interpretation and reinterpretation. As Saayman depicted the DRC mission history as a problem-saturated narrative, it is argued that unique outcomes also reside within this problem-saturated narrative, creating the possibility for the re-authoring of a liberated mission narrative. It is suggested that the narrative strategies of externalisation and co-authoring can be instrumental in attaining a mission narrative that is truly human.

Keywords: Willem Saayman; Dutch Reformed Church; mission history; religious tradition

\section{INTRODUCTION}

The renowned South African missiologist, Emeritus Professor Willem Saayman, passed away on 16 May 2015. One of his greatest academic contributions was

\section{UNISA $\cong$}


arguably the comprehensive overview of the Dutch Reformed Church (DRC) mission history entitled Being missionary, being human (2007).

In the introduction of his book, Saayman $(2007,14)$ stated: 'I am rather interested in understanding the DRC, its mission, and therefore myself, better in order to be a better servant of the missio Dei.' He continued by saying that 'I am writing therefore specifically from an insider's perspective'. In this way, Saayman $(2007,6)$ engaged in a personal narrative in which he identified the DRC with its mission - and its mission with it, thereby recognising the intrinsic unity, but also the distinguishable character of mission history within church life. According to him, the DRC has always understood its own purpose as glorifying God, building the faith of the local congregation and expanding the Kingdom of God by engaging in mission. A clear mission history is thus apparent (see Crafford 1982; Cronje 1981) and can be examined as such, but not without examining the DRC history itself.

Saayman (2007) set out to analyse this history via a periodisation in terms of 'four waves', each referring to a period of distinguishable upsurge, change in direction and new motivation for mission in the DRC. The four waves that were identified by him are the following: 'Early Dutch Reformed mission', 1779-1834 (pp. 15-44); 'Crossing borders', 1867-1939 (pp. 45-68); 'Crossing inner boundaries', 1954-1976 (pp. 69-99); and 'To the ends of the earth', 1990- (pp. 100-124). In the process of analysis, he explored the role of the political, social and economic factors that constructed the mission narrative of the DRC since its founding in South Africa until the dawn of the new democracy in the mid-90s. Saayman boldly identified the two dominant understandings or paradigms for mission operative in the DRC during this period. In this regard, he stated that the DRC mission was driven by the understanding that:

- 'Mission is essentially evangelistic, concentrating on the conversion of Gentiles and the planting of churches; and

- Mission is done by white people to black people, in other words the "subjects" of mission are white and the "objects" of mission are black' (see Saayman 2007, 7).

The narrative that Saayman then allowed to unfold can be typified as poignant, provocative and even upsetting, because, while maintaining that 'nobody can credibly deny the proud mission history of the DRC' (Saayman 2007, 139), he also maintained that 'racism' ran like 'a fault line' through the DRC mission history (ibid, 129), which led to an ecclesiastical heritage of segregated worship that is still part of daily DRC life. This situation was vehemently opposed by Saayman, as he stated unequivocally in his concluding remarks $(2007,130)$ : 'The continued existence of a racially divided DRC...cannot be accepted nor can it be theologically justified or explained away.'

Sadly, Saayman passed away in the very same year that yet another attempt at structural unification between the DRC and the Uniting Reformed Church failed, leaving an open end to a narrative that appealed to its listeners to become 
unconditionally human in their missionary endeavours and faith (Saayman 2007, 139). (The author refers to the DRC's failed attempt at altering the first article of the Church Order in order to make the Belhar Confession part of its confessional base, a prerequisite that has been maintained by the Uniting Reformed Church on the road to structural re-unification with the DRC.)

Consequently, Saayman's rendition of the DRC mission history will be revisited from the perspective of narrative theory. The purpose of this engagement is an attempt to reinterpret Saayman's understanding of mission history within a narrative framework, as it allows for the formulation of alternative narratives by altering one's relationship with previous narratives. In this instance, it is suspected that strategies which have been developed from narrative theory can be helpful in altering our relationship with the historical text of the DRC missionary history, when this text is treated as a narrative that can be reinterpreted, thus showing the importance of Saayman's contribution in the quest for new paradigms for mission and a new narrative for the DRC.

\section{CONCEPTUAL FRAMEWORK AND OUTLINE OF THE RESEARCH}

The notion of a narrative interpretation of life and experiences has been present for some time. In the early 70s, Crites (1971) had already suggested that the human experience contains a narrative quality that causes persons to understand their lives and actions as stories. According to Ganzevoort $(2012,216)$, the ensuing theorising, especially by hermeneutical philosopher, Paul Ricoeur, led to what he describes as a 'narrative turn' in human and social sciences and a broadening of the way in which reality can be understood. Whereas Ricoeur (1984-1988) argues that not only physical texts, but also human actions are exercised in a time sequence, Ganzevoort contends that 'our collective identity, history, and religious traditions are likewise structured as stories' and can therefore be considered as texts that are open for interpretation and reinterpretation. This opens up the possibility to revisit historical texts by reinterpreting (relocating) them within a narrative framework. By relocating narratives about the past in this way, a better understanding of our problem, saturated in (hi)story (and current reality), can possibly transpire. This becomes especially necessary when historical texts are problem saturated to the extent that they inhibit growth in the present. The narrative theory of White and Epston (1990) suggests that the stories we tell about the past can make it impossible for us to live in the present and to move forward. If this is the case, stories need to be retold in order to discover unique outcomes on which liberating stories can be built. It is in this framework that Saayman's history of the DRC mission will be revisited.

In this endeavour, at least the following aspects warrant further discussion: As point of departure, the narrative theory and strategies of White and Epston (1990) will 
be elucidated. Although White and Epston gained recognition for their narrative work in the field of therapy, the strategies that they developed for facilitating a narrative approach seem highly suitable when historical texts are also deemed as narratives. Therefore, a summative description of White and Epston's narrative theory will be provided, as well as a cursory discussion of the strategies that emanated from it. An engagement with the DRC mission history according to Saayman will follow and the most prominent aspects of his 'four waves' will be highlighted. This will enable a relocation of Saayman's history of the DRC mission within a narrative framework from which suggestions for a liberating mission narrative will hopefully follow.

\section{THE NARRATIVE THEORY OF WHITE AND EPSTON}

As has been suggested, this research will align theoretically with the notion of the narrative as put forward by Michael White and David Epston in their book, Narrative means to therapeutic ends (1990). In this collaborative project, they explored the idea that people's knowledge about reality is based upon their 'lived experience' (White and Epston 1990, 9). To make sense of this 'lived experience', the experience is 'storied' (ibid, 10). When past and present experiences of events and expectations of future experiences are linked in a lineal sequence, a so-called 'self-narrative' is created. This 'storying' of the lived experience of people becomes the shaping agent of what they perceive as their reality. It is a complex process, as the lived experiences of people develop within a broader sociopolitical context. Sociopolitical contexts often provide dominant discourses that exert a formative influence on the storying process and can include ideologies, perceptions and beliefs (ibid, 10, 26). Like the sociopolitical context, language also exerts a formative influence on the narratives of people via the so-called 'truth discourses' that are present in societies and expressed in language (ibid, 27). In this way, truth becomes socially constructed and has the capacity to influence and direct the way in which people lead their lives.

\section{Problem-saturated stories}

When conflict develops between the lived experiences and the storying of these experiences, a problem-saturated story, creating a need for the generation of alternative stories, results (White and Epston 1990, 15). This happens when the relationships between people and their narratives become problematic in the sense that they keep people from changing for the good or from moving forward. If a certain narrative of socially constructed beliefs about others, for example, exists, or is dependent upon certain values that the owner sees as true, it will inhibit growth in terms of thinking about and behaviour towards others. In this sense, the relationship with a narrative can become problematic and needs to change. 


\section{Externalisation}

This is a strategy that helps to create a context in which persons can experience themselves as separate from their problem-saturated stories or from the problems that they perceive to be the reason for such problem-saturated stories (White and Epston 1990, 38). Creating this distance makes it easier to think more objectively about the relationship with these problems as well as to modify the relationship with it. This process can also involve the 'naming' of problems (O'Hanlon 1994, 24) in order to deal with them more effectively, or personifying them (Morgan 2000, 25). Usually, externalisation goes hand in hand with deconstruction, a technique that refers to the scrutinising of culturally influenced ways of thinking and assumed truths in order to recognise their implications and influence so that people can decide to distance themselves from them if they form part of their problem-saturated stories (Payne 2006, 84).

\section{Unique outcomes}

A unique outcome can be anything that does not fit in with the problem-saturated story (Morgan 2000, 52; White and Epston 1990, 55), in other words, instances where people are not bound by the beliefs or language that constitutes the problemsaturated stories. The unique outcomes need to be identified, as they can serve as clues, gateways or starting points for alternative stories; they pay testimony to the fact that people do not need to be bound by current narratives. These instances thus demand careful scrutinising and analysis in order to continue building on them as a way of altering a problem-saturated story.

\section{Constructing alternative stories}

This can be deemed as the outcome or goal of the narrative process (White and Epston 1990, 15). Whereas problem-saturated stories inhibit life and growth, alternative stories that are built on the unique outcomes nurture and promote alternative narratives. Over time, these alternative narratives need to be reinforced in order to strengthen them. Key to the constructing of alternative narratives is the process of co-constructing or co-authoring that, according to Müller (2000), underlines the importance of others, because in narrative theory, other people have the role of cotravellers who help us to discover new and liberating stories. This demands a true curiosity about the narratives of others and obliges us to take them seriously.

Although these strategies evolved from the personal experience of White and Epston in a therapeutic setting, it is suggested that the strategies can be useful in altering the relationship that we have with historical texts or narratives. The reason for this (as stated before) is that our collective identity, history, and religious tradition are likewise structured as stories and are therefore open to interpretation or reinterpretation. 


\section{THE MISSION HISTORY OF THE DUTCH REFORMED CHURCH ACCORDING TO WILLEM SAAYMAN}

In the following discussion, Saayman's account of the DRC mission will be put forward in a cursory fashion. This method obviously poses two important challenges. The first challenge is to distinguish the most important elements of Saayman's account. As this relies on the author's personal understanding, the 'listening' process will certainly be subjective. Therefore, no claims are made that Saayman's rendition is here retold objectively. The second challenge is to relay Saayman's narrative in the confined space of an academic journal article. This will force the author to be even more selective, which poses more challenges to the objectivity of the project. The underlying account should thus be understood as one perspective, recognising that different understandings of the same narrative are possible.

\section{The first wave (1779-1834)}

The starting point for the first wave (surge) of the DRC mission activity is set at 1779, because no marked or sustainable mission acts were recorded from 1652 to 1779. However, the efforts of Helperus Ritzema van Lier and Michiel Christiaan Vos introduced a 'qualitative different period' (Saayman 2007, 28), characterised by organised and sustained mission fervour among indigenous natives and slaves. Although this was met with some resistance from slave owners who were afraid of financial loss due to government regulations prohibiting the sale of baptised slaves, Van Lier pursued the evangelisation of indigenous workers and slaves (Saayman 2007, 34). It is not surprising then that the mission fervour of Van Lier and Vos reflected in several decisions of the synods from 1824 to 1834 . By 1824, a general plan for the religious instruction of non-Christians within the boundaries of the DRC was in place, but was marred in 1829 by the emergence of the question before the Synod about interracial worship (Holy Communion). The response of the DRC Synod was clear, stating that 'nobody could be excluded from worship on the grounds of race alone' (Saayman 2007, 36). As a footnote to this, Saayman observed that this question did not serve at the Synod because of theological doubts about the question of interracial worship, but rather as a result of the hardening of racial attitudes in some congregations that were unwilling to allow interracial administering of Holy Communion. The DRC's position on racial equality was further expounded on at the Synod of 1834 when it decided that baptised and catechised heathens (blacks) were considered full members of the local DRC congregations where they were baptised. Another important decision for the mission work of the DRC was that the Synod requested DRC ministers to propagate mission, also through so-called mission institutes if any of them operated in the boundaries of the congregation at the time.

Some of the noteworthy sociopolitical factors during this time included the following: the rise of ethnocentrism amongst whites became a visible trend at the 
time. This was mainly attributed to European stereotypes that were held about people of colour and reinforced by perceptions of Western/white superiority. It occurred when 'civilisation' and 'Christianity' were equated. Resulting from this ethnocentrism was the unfortunate caste system in Cape colonial society, where the dominant caste was white and the lowest caste black (Saayman 2007, 21). Another worrying phenomenon was the acceptance of slavery as basis for the whole social order, a phenomenon that was not challenged by anyone during this period; not even Van Lier or Vos questioned the hierarchical nature of the system. Because of this pragmatic acceptance of the status quo, it was accepted as a 'necessary evil' (ibid, 22). In the light of this, uneasiness between 'masters' and 'slaves' resulted when, through baptism, people of colour fell in the same religious and cultural tradition as their owners (ibid, 23). On a social level, the emergence of racial stereotypes seriously strained the relationship between whites and people of colour within the church.

Another important event during this period was the emancipation of slaves in 1834 by British rule; this led to dissatisfaction amongst frontier farmers and paved the way for the so-called Great Trek. The dissatisfaction amongst frontier farmers was mainly as a result of 'unjust' compensation for slaves and the resulting shortage of labour, prompting Saayman $(2007,38)$ to comment that 'it obviously meant that interest in...mission had to wane'. Although the moving of farmers outside the borders of the Cape colony would bring them into contact with Africans, it is not known whether they proclaimed the gospel to them; it seems as if they rather engaged in clashes as part of a new struggle for survival (ibid, 43). Constructive mission within the DRC would, for the time being, have to submit to more burning issues within the DRC, like the challenges emanating from the Great Trek; 1834 thus also became the terminus ad quem of the first wave (ibid, 38).

\section{Interlude: The DRC Synod of 1857}

Because Saayman's second wave is denoted as starting in 1867, a short interlude to note the DRC Synod of 1857 is necessary, as it falls between the first and second wave. While Saayman did note this Synod by means of a footnote (2007, 37), it still requires closer attention for a comprehensive understanding of the DRC mission narrative.

The interracial worship question that had been put to the Synod of 1829 was raised at the Synod of 1857 again. Although the Synod corroborated their 1829 stance, a compromise decision was added that sanctioned separate communion between black and white members when it would seem that joint communion would hinder the spreading of the gospel; yet, 'synod again stressed the biblical injunction [own italics] that no differentiation could be made between Christians on the base of race alone' (Saayman 2007, 37). 
The relevance of this watershed decision is that it emphasises the underlying racial tension in the society of the time, a tension that apparently grew since the Synod of 1829 amongst members of the DRC too; it also led to segregated worship, because there exists a general distinction between the 'black' reformed church family and the 'white reformed church family' since this decision. The white reformed churches became known as the 'sister churches', whereas the black reformed churches became known as the 'daughter churches'. Within the framework of racial segregation, even the terms 'mother, sister and daughter churches' became problematic, as they not only emphasised the differences between believers, but also suggested some kind of hierarchy.

With regard to the 1857 decision of the Synod, Saayman's frank and bold use of the term 'racism' is notable, as he stated that through this decision, 'the presence of racism in the life and structures of the DRC would be revealed more clearly' (Saayman 2007, 37). Sadly, it would thus seem that other factors besides theological considerations were steering the DRC's actions at the time.

\section{The second wave $(1867-1939)$}

Irrespective of the fact that Saayman $(2007,46)$ chose 1867 and the discovery of diamonds in Kimberley as the starting point of the second wave, this period was linked to the Synod of 1857 by the decision to appoint a Missions Committee to manage the DRC's mission work, both within and outside the Colony (ibid, 50). The mission fervour of the first wave was thus carried forward by the structures of the DRC.

As the focus during this period was on mission outside the borders of the Cape, the second wave is denoted by 'crossing borders'. Due to the lack of availability of missionaries within the colony's borders, missionaries had to be called from overseas. By this time, however, mission ventures within the borders of the South African Republic (SAR), as the Transvaal was known, would not be welcomed, because clear differences on the matter of race equality between the Cape and the SAR existed. Apparently, it was engrained in the Constitution of the SAR that no equality between black and white could exist, whereas racial equality was propagated in the Cape colony (Saayman 2007, 51). As the few mission opportunities in the SAR were occupied by missionaries from mission societies, a new quest for mission fields further afield became visible. The Minister's Mission Association that originated in the Cape (1886) subsequently heeded calls from Scottish missionaries in Nyasaland (currently called Malawi ) and joined in attempts to reach the slaves from Central Africa with the gospel (ibid, 53), making slaves the common denominator between the first and second wave. Later on, DRC missionaries also went to Mashonaland (later called Rhodesia and currently Zimbabwe), but this was not sustainable. 
In the Orange Free State (currently called the Free State), the DRC's mission 'across borders' started much later when two DRC missionaries became involved in mission in the northern parts of the then Rhodesia in 1899. This delay in the Orange Free State's participation was mainly due to a marked reluctance, based on racial indifference, on the side of congregation members towards mission (Saayman 2007, 56). Early during the second wave, the DRC's involvement outside the country's borders was thus firmly established.

Unfortunately, the pressing matter of the Second Anglo-Boer War (1899-1902) caused the focus on mission to wane rapidly. Apart from the obvious devastating effects on the DRC's members at large, a dualistic influence was exerted by the war in terms of the DRC's mission work. On the one hand, relationships between black and white South Africans deteriorated further as a result of the British army's use of blacks in a supportive role in the war (Saayman 2007, 58). On the other hand, a new awakening towards mission occurred as a result of the way in which Afrikaners interpreted the reasons for the war (i.e., they believed that God was reminding them of a deeper purpose in life). From this awakening, mission associations such as the 'Transvaal Women Missionary Association', 'Commando's Gratitude Mission Society' and 'Boeren Zending School' came into being, attesting to a new awareness of a higher calling (ibid, 61).

This higher calling still translated into the evangelisation of 'heathens' (Saayman 2007, 68), although a qualitative difference in comparison with the first wave was the mission efforts in areas such as Malawi and Zambia that were accompanied by social services like medical and educational services in the wake of missionary work.

\section{The third wave (1954-1976)}

Of the four waves, the third presents itself as probably the most poignant, as Saayman here accounts for the role of apartheid in the DRC mission history. In Being missionary, being human (2007), the third wave spans 31 pages in which Saayman offers an interpretive narrative of apartheid's origin and influence in the DRC and its mission, while at the same time explicating some of its repercussions. This section in particular begs for a reading of Saayman's own text, because a cursory approach cannot do justice to the original narrative. As Saayman's periodisation rests on surges in the DRC's mission activities, the third wave is indicated with 1954 as the starting point and is subtitled 'Crossing inner borders' (Saayman 2007, 69). Noticeably, Saayman's narrative starts much earlier with reference to decisive changes in the South African political landscape due to the National Party's election victory in 1948, once again stressing the interwoven character of historical narratives, in this case the interwoven nature of national, church and mission history.

What made the National Party's coming into power so important was that it brought with it the system of apartheid that would play a decisive role over (at least) the next 40 years. Of critical importance is Saayman's notion that apartheid did not 
come into being in 1948 as the brainchild of the NP, DRC and white farmers, but that 'it was firmly rooted in nearly 300 years of Western colonialist ethnocentrism and racism, equally practised in South Africa by Dutch, British and South African governing authorities with the near unanimous support of Dutch, French, English, Scottish and German colonists' (Saayman 2007, 70). As indicated, important decisions (such as those of the Synod of 1857 that facilitated segregated worship) were in place long before the term apartheid was coined. Unfortunately, as Saayman points out, there can be no denial that the National Party and the DRC played the pivotal role in perfecting this system of social engineering. In this regard, Saayman quotes Giliomee $(2003,454)$ who reminded the reader that the first printed record of the term apartheid is from a paper that was read by Rev. J.C. du Plessis at a mission congress in 1929 at Kroonstad, as apartheid was the fundamental idea of mission, aimed at the 'independent national future' of all blacks. This stance was reiterated by Rev. Valie Strydom when he equated apartheid to DRC mission policy (see Giliomee 2003, 458). Adding to this, the 1950 Bloemfontein Federal Mission Council of the Federated Dutch Reformed Churches in SA unabashedly claimed ownership of this system in an attempt to address the so-called native question (ibid, 71) [own italics]. The DRC's role in apartheid (as it transpired through its mission policy) became therefore engrained in the DRC's (hi)story. It justified the system theologically as something that would create a framework in which the Afrikaners could maintain their racial purity in a just political dispensation.

On the political front, two reports from commissions that were appointed by government, namely the Tomlinson and Eiselen Reports, accelerated this system of social engineering (Saayman 2007, 72). The Eiselen Report on Black Education (1950) eventually led to the institution of black farm schools as preventative measure against black children going to public schools (ibid, 79). Black farm schools, as opposed to farm schools, only provided elementary training to the children of farm workers, aimed at teaching them to read the Bible with no intention of progressing to a secondary level. It was an education system that effectively only empowered learners to become better workers. This clearly illustrates the underlying view of the policy, namely that black people are workers. Saayman (2007) has drawn an articulate difference between farm schools as institutions in rural areas that provided education for pupils of all colours, and black farm schools that were under the direct control of white farmers and only provided a fundamental training for farm workers' children.

While the Eiselen Report (1950) attended to education, the Tomlinson Commission had socioeconomic concerns, as it was aimed at the advancement of the black homelands system. The Tomlinson Report, stemming from its investigation (1954), strung a lot of mission chords, as it indicated how mission could aid nationalistic goals, both locally and in the rest of the sub-continent. In the wake of this report, a notable surge in the number of DRC mission vocations became visible in the Eastern Cape and Limpopo. This surge was reinforced by the government's decision 
to aid the DRC financially for the erection of mission stations, church buildings and medical facilities (Saayman 2007, 75). In another guise, this rekindled mission fervour spread into the rural areas of South Africa via a surge in the number of black farm schools that doubled as churches on Sundays on farms in white ownership. Suddenly, great numbers of nationalist Afrikaners became involved in a peculiar form of mission in which mission and national existence were now bedfellows (ibid, 90). The link between mission and apartheid was, however, now firmly cemented. In a certain sense, the seed of the Synod of 1857 had now grown into full fruition:

In this way, general Western ethnocentricity and ethnosuperiority of the early settlers developed in the social and missionary context into a theologically substructured racist superiority in which service to the fatherland can be equated to participation in the missio Dei. (Saayman 2007, 90)

As could be anticipated, the direction of this path changed as black resistance grew, culminating in the many well-known beacons of liberation history and, at the same time, building the bridge to Saayman's fourth and final wave.

\section{The fourth wave (1990-)}

Whereas the third wave was characterised by the rise and fruition of apartheid, the last wave was characterised by its fall and the demise of white minority rule. Henceforth, the close relationship between the ruling National Party and the DRC ceased to exist, throwing whites and the DRC into an identity crisis - even a 'postapartheid depression' (Saayman 2007, 105). (For a more elaborate and in-depth discussion of the emotional and psychological impact of the fall of minority white rule in South Africa, see Saayman 2007, 103-106.) This crisis caused mission to fall in limbo. Not only did enthusiasm for mission wane, but the focus of mission disappeared as the DRC lost their mission objects, because (in light of the new dispensation) the subjects and objects were now equal. By this time, South African missionaries were also under suspicion, as their ethnocentric approach was wellknown everywhere; their presence in Africa thus started to diminish (ibid, 108). New mission objectives had therefore to be set. According to Saayman $(2007,106)$, this became evident in a comparison between the DRC's 1938 and 1998 mission statements in which it becomes visible that the scope of mission was widened drastically from 'this country' to 'the ends of the world'. On a practical level, mission also became 'decentralised' from synods to local congregations, with the scope no longer local black communities, but the world itself (ibid, 118). This resulted in a multiplicity of mission projects that were facilitated by the DRC, but not necessarily supported by a sound theological theory (ibid, 119). It is, however, not to say that Africa disappeared from the DRC's scope. Saayman $(2007,117)$ pointed out that the DRC verbalised early in the new millennium a renewed commitment 'to the 
continent of Africa' as well as a 'special desire to unite with other churches of the DRC family'. (See the 2002 DRC General Synod's Statement of Vocation.)

Concluding his narrative of the DRC mission with an appeal that mission, as it transpired in the DRC, needs to be humanised, Saayman $(2007,125)$ stated that 'the reality of the incarnation of Christ as Jesus of Nazareth... compels us to be missionary as we are being human'. The problematic relationship between racism and mission enthusiasm was ever present in this narrative, much like a 'fault line' (ibid, 129). This led to a 'dehumanisation' (ibid, 135) that prevented the DRC mission to recognise black South Africans as fellow human beings who are created in the image of God. In Saayman's opinion, such humanisation can only become a reality if mission, amongst others, can become self-transcendent $(2007,129)$, racism can be defeated (ibid, 130), unity can be realised (ibid, 130) and the DRC can succeed in acquiring a new identity that will include the 'destitute, the wronged and the oppressed' and exclude white separatism (ibid, 134). This humanisation could only be ignited by 'an open and public acknowledgment of the DRC's role and institutionalisation and maintenance of apartheid' (ibid, 135).

\section{A NARRATIVE REFLECTION ON THE MISSION HISTORY OF THE DRC ACCORDING TO WILLEM SAAYMAN}

\section{A problem-saturated (hi)story}

Seen within a narrative paradigm, Saayman's portrayal of the DRC mission represents a restrictive, problem-saturated (hi)story; one that most certainly did not leave sufficient space for the performance of what Saayman believed to be the true essence of mission, namely a mission that was also truly human. Built on a problematic paradigm, that mission is essentially something that a subject (white) does to an object (black); a restrictive narrative was thus in the making. As dominant narratives are also heavily influenced by sociopolitical discourses and ideologies (in this case white ethnocentricity), the woeful Synod decision of 1857 stands in line with the socially constructed truths that were maintained by the society of the time. The fact that slavery was never questioned by mission, not even by the fervent Van Lier and Vos, was perhaps a clue to the power of these socially constructed 'truths'. This not only carried mission through the first two waves, but also paved the way for the DRC's commitment to the social engineering project of apartheid, even proclaiming ownership of it and providing theological justification for it. In a certain sense, it is hard to count the ways in which this lack of differentiation made the DRC mission story restrictive. The power it exerted is, however, still visible today, with some DRC members earnestly trying to re-author a new narrative, whereas others still lead their lives according to the past. In narrative theoretical terms, the DRC 
mission (hi)story demonstrates the powerful formative influence of ideologies and perceptions that lead to a problem-saturated story that has inhibited growth towards a liberated narrative of a humanised mission.

\section{UNIQUE OUTCOMES?}

In the way that Saayman has narrated the DRC mission history, three unique outcomes seemed to transpire, namely instances where the DRC mission narrative was not controlled by the dominant discourses that otherwise made it problem saturated. What can then be regarded as clues in this (hi)story that can still be pursued in the DRC's current quest for a liberated narrative?

The first and foremost unique outcome took place when the DRC was formally interrogated for the first time during the Synod of 1829 on the issue of segregated communion. The Synod's 'clear pronouncement' that nobody could be excluded from worship on the grounds of race alone was certainly a theological one, as Saayman pointed out that the question did not arise from theological doubt amidst the church leadership (Saayman 2007, 36).

The second unique outcome in this regard followed shortly after the first when the Synod of 1834 decided that non-whites who were baptised and catechised had to be recognised as full members of such DRC congregations, recognising that no distinction amongst people should be made on the grounds of race. What both these unique outcomes had in common, were the bold application of theological principles (or, in narrative theoretical terms, the application of God's Grand Narrative, the Bible) where socially constructed 'truths' threatened to create a problem-saturated discourse.

The third unique outcome only followed during the fourth wave in which new discourses like equal partnering, forgiveness and a shift in mission focus entered the narrative, breaking the old paradigm (discourse) that mission is something that white people 'do to' black people. When recognised as unique outcomes within a narrative framework, these instances supply valuable clues that can still be explored further within the current dispensation. It urges us, for example, to investigate anew the role of true theological discourse when the Christian narrative is threatened by socially constructed discourses, consequently investigating what the role of equal partnering, forgiveness and so forth can play in the current situation of the DRC.

However, in a critical assessment of Saayman's account, the identification of only three unique outcomes is somewhat problematic. If the intrinsic unity between the DRC's church and mission history is maintained, it can be argued that many more unique outcomes exist. The following examples serve as proof of this argument: In 1986, the DRC accepted the document Kerk en samelewing (Church and society) in which membership of the DRC was declared open for all races, the biblical justification of apartheid was declined, mixed marriages on the grounds of race were no longer denied biblically and the importance of church unity was 
stressed. In 1990, the late Prof. Willie Jonker publicly confessed the sin and guilt of supporting apartheid on behalf of himself and the DRC and begged the forgiveness of those who suffered as a result of it. (For a more elaborate discussion of some of the DRC's attempts to address the consequences of their support for apartheid and their commitment to the process of reunification, see Brunsdon 2013.) It is also known that after the dawn of the new democracy, the DRC embarked purposefully on a new journey towards reunification via its structures.

These examples show that there are many more unique outcomes that are embedded in this narrative that can aid the process of re-authoring and that should have formed part of Saayman's account. Irrespective of their omission, these outcomes beg for further theological consideration, as they were instrumental in steering the problem-saturated DRC narrative in a new direction, giving the church clues as to what could aid the current narrative even further.

\section{Externalisation and the co-authoring of a liberated mission narrative}

In the final chapter of Saayman's narrative, several suggestions in terms of finding an appropriate paradigm for the DRC mission were made. Amongst others, the importance of academic training, better organisation of mission, and clarity in policy on synod and congregational level were discussed (Saayman 2007, 127128). Ultimately, however, Saayman pleaded that the DRC mission had to become human, stating that 'we can only participate in the mission of Jesus if we are wholly human' (ibid, 139). In contrast, the mission history of the DRC was inhumane, as the fault line of racism was always present. Hence, Saayman's narrative compelled him to appeal for urgent unity in the DRC family and the abolition of a theological discourse that is 'still preoccupied by white separatism' (ibid, 134), an abolition that can only be attained by 'an open and public acknowledgement of the DRC's role and institutionalisation and maintenance of apartheid' (ibid, 135).

While Saayman's appeal is valid within the context of his historical account, it seems highly unlikely within the current DRC and South African contexts that DRC members will agree to yet another confession (Saayman 2007, 135). As this research was underway, the majority of DRC congregations responded negatively to the General Synod's proposal to alter the current Church Order to accommodate the Confession of Belhar as precursor to the unification process with the Uniting Reformed Church. On a national level, all indications are that we are faced with a growing distrust amongst the different races rather than a growing reconciliation.

However, relocated within narrative theory, the possibility of externalisation becomes available as a process in which DRC members can engage actively with constructs like separatism, racism and even apartheid in a non-threatening way, creating a safe space in which these limiting discourses can be deconstructed and recognised for what they are to keep them clear from future narratives. This process 
becomes even more necessary when it is kept in mind that a discernible portion of current DRC members were not part of the 'apartheid generation' and don't perceive themselves as owners of the historical narrative of the DRC. It is therefore contended that a pastoral engagement with congregations to facilitate externalisation and deconstruction of problematic discourses is more feasible than the route that has been suggested by Saayman.

Eventually, narrative theory accommodates the formation of freeing stories, where the process of co-authoring is central. Sadly, as Saayman's narrative suggested, the notion of equal partnering should have been part of the DRC narrative, but it did not happen (Saayman 2007, 131). A big part of the DRC's restrictive history was that it became a church 'without others'. When the DRC mission narrative is reinterpreted in a narrative fashion, the implication is that the formation of new paradigms for mission - and eventually a new narrative for the DRC - should be done with others, making an active engagement with other believers non-negotiable. The heart of the narrative journey is that it is a journey with others, being truly curious about the narratives of others and how they can help in the construction of freeing stories. Ultimately, it comprises the construction of a new narrative in the light of God's Grand Narrative, because we are not busy with our own story, but merely participating in the realisation of God's narrative.

\section{CONCLUSION}

This article engaged the DRC mission history as narrated by the late Willem Saayman. The central theoretical argument was that historical texts can be read as narratives that are open for reinterpretation, creating the opportunity for the reauthoring of problem-saturated narratives. Relocating Saayman's account of the DRC mission within the narrative theory of White and Epston has indicated that the DRC mission narrative can definitely be deemed a problem-saturated one, as it rested on a wrongful mission paradigm and was guided by the public discourses of white ethnocentricity and racism. However, several unique outcomes were also embedded in this narrative, providing clues for the construction of a liberated narrative. Even more unique outcomes are to be found if the intrinsic unity of the DRC history and mission history is acknowledged, amongst them adhering to God's Grand Narrative as found in Scriptures and the active application of them in church life. Contrary to Saayman's proposal of another confession of the DRC's responsibility for apartheid, this article suggested the narrative strategy of externalisation and deconstruction as means of altering the DRC community's understanding of the implications of socially constructed ill practices such as apartheid and white separatism. It was suggested that a pastoral engagement between stakeholders should be considered in order to facilitate externalisation and deconstruction of problematic discourses. This may pave the way towards a co-authored and liberated mission paradigm, as dealing with the past can lead to renewed dialogue between the DRC and members of the 
DRC family so that the DRC may eventually participate in the mission of Jesus in a truly human way.

\section{LIST OF REFERENCES}

Brunsdon, A.R. 2013. 'The confined public good of a confession: A practical public theological reflection on enhancing the (public) good of the Belhar Confession in the Reformed church family of South Africa.' Paper presented at the Oxford Round Table on Religion: An interdisciplinary perspective, Brasenose College, Oxford, 30 July.

Crafford, D. 1982. Aan God die dank: Geskiedenis van die sending van die Ned. Geref. Kerk binne die Republiek van Suid Afrika en enkele aangrensende buurstate. Deel I. Pretoria: NGK Boekhandel.

Crites, S. 1971. 'The narrative quality of experience.' Journal of the American Academy of Religion 39: 391-411.

Cronjè, J.M. 1981. Aan God die dank: Geskiedenis van die sending van die Ned. Geref. Kerk buite die Republiek van Suid Afrika. Deel II. Pretoria: NGK Boekhandel.

Ganzevoort, R.R. 2012. 'Narrative approaches.' In The Wiley Blackwell companion to practical theology, edited by B.J. Miller-McLemore, 214-223. Chichester: Wiley-Blackwell.

Giliomee, H.B. 2003. The Afrikaners: Biography of a people. Cape Town: Tafelberg.

Morgan, A. 2000. What is narrative therapy? Adelaide: Dulwich Centre Publications.

Müller, J. 2000. Reisgeselskap. Wellington: Lux-Verbi. BM.

O'Hanlon, B. 1994. 'The third wave: Can a brief therapy open doors to transformation?' The Family Networker (Nov/Dec): 19-29.

Payne, M. 2000. Narrative therapy: An introduction for counselors. London: Sage Publications.

Ricoeur, P. 1988. Time and narrative. Chicago: University of Chicago Press.

Saayman, W. 2007. Being missionary - being human: An overview of Dutch Reformed mission. Pietermaritzburg: Cluster.

White, M. and D. Epston. 1990. Narrative means to therapeutic ends. New York: W.W. Norton \& Company. 